\title{
Industrial Wastewater Treatment by Using MBR (Membrane Bioreactor) Review Study
}

\author{
Saima Fazal*, Beiping Zhang, Zhenxing Zhong, Lan Gao, Xuechuan Chen \\ Department of Environmental Sciences and Engineering, Huazhong University of Science and Technology, \\ Wuhan, China \\ Email: saimafazal@hust.edu.cn
}

Received 24 April 2015; accepted 22 June 2015; published 26 June 2015

Copyright (C) 2015 by authors and Scientific Research Publishing Inc.

This work is licensed under the Creative Commons Attribution International License (CC BY).

http://creativecommons.org/licenses/by/4.0/

(c) (i) Open Access

\begin{abstract}
This study demonstrated the importance, process, activation and applications of Membrane in bioreactor to treat the waste water. Membrane Bioreactor (MBR) process consists of a biological reactor integrated with membranes that combine clarification and filtration of an activated sludge process into a simplified, single step process. Operating as an MBR allows conventional activated sludge plants to become single step processes, which produce high quality effluent potentially suitable for reuse. Application of MBR technology for industrial wastewater treatment has also gained attention because of the robustness of the process. Theoretically, maintenance of long SRT in MBR is in favor of the retention and development of special microorganisms, which may lead to better removal of refractory organic matter and make the system more robust to load variations and toxic shocks. Literature suggested the conceptual expectation of enhanced biodegradation of hardly biodegradable compounds in MBR does not often come true. Improved biodegradation to certain extent has been reported in a few studies; however the underlying factors leading to such improvement still remains to be elucidated. This is comprehensive review of the studies dealing with recalcitrant industrial wastewater treatment by MBR, and casts light on the strategies to achieve enhanced biodegradation of hardly biodegradable industrial pollutants in MBR.
\end{abstract}

\section{Keywords}

MBR, Waste Water Treatment, Sludge Research

\section{Introduction}

Industries have usually different production and large changes in product categories, which increases the diffi-

\footnotetext{
*Corresponding author.
} 
culty of industrial wastewater treatment. Industrial wastewater treatment methods commonly used chemical and biological methods. Among these methods, biological treatment is currently widely used in industrial wastewater treatment, which is the most economical and environment friendly. Every method has become the focus of research and application. There are many reasons to use more SBR (Sequencing Batch Reactor) Act, CASS (Cyclic Activated Sludge System) Act, ICEAS (Intermittent Cycle Extended Aeration), oxidation ditch, as the main contact oxidation process at the current domestic and international industrial wastewater treatment technologies, but because of the waste water deposit in inhibitory substances and refractory organics, leading to the treatment effect of these methods are not ideal.

Increasing industrialization trend in the worldwide has resulted in the generation of industrial effluents in large quantities with high organic content, which if treated appropriately, can result in a significant source of energy [1]. Industrial wastewater contains large amounts of suspended material, through the efficient separation membrane these suspended solids and turbidity of the wastewater come close to zero. In addition, due to the wastewater contains toxic substances, which easily lead to sludge swelling phenomenon occurs at the membrane separation, not resorted to water quality is affected [2].

MBR (Membrane bioreactor) technology is an excellent modern wastewater treatment technology, having the several advantages over conventional activated sludge processes [3]. Membrane bioreactor technology is a membrane separation technology and bioorganic combination of new wastewater treatment technology. It utilizes membrane separation activated sludge and biochemical components of the reaction cell. Organic molecules trapped in place of the secondary settling tank, increase the concentration of activated sludge and ensure water quality, thus greatly strengthening the function of the bioreactor [4]. Membrane Bioreactor (MBR) process is a hybrid system amalgamating membrane separation with biological treatment. Operating as an MBR allows conventional activated sludge plants to become single step processes, which produce high quality effluent potentially suitable for reuse [5]. Almost all of the activated sludge in the reactor can stay inside membrane instead of the secondary settling tank and effectively improve the sludge concentration up to MBR $18000-19000 \mathrm{mg} / \mathrm{L}$ [6].

Membrane bioreactor (MBR) is a biochemical engineering process involving the use of both 1) a suspended growth bioreactor for biochemical reactions (such as fermentation, bio-oxidation, nitrification, and denitrification) and 2) a membrane separator for subsequent solids, liquid separation [7]. Use of micro and ultra-filtration membranes combined with anaerobic reactors will be another post-treatment option. A combined lab scale system consisting of up flow anaerobic sludge blanket and Membrane bioreactor has shown the approximately COD removal efficiency of $98 \%$ and $100 \%$ in TSS (total suspended solids) removal of high strength enriched municipal wastewater [8]. The Principle of this technique is nearly the same as activated sludge process, except that instead of separation the water and sludge through settlement, the MBR method uses the membrane which is more efficient and less dependent on oxygen concentration of the water [9].

Over the past decade, submerged membrane bioreactor (MBR) processes have experienced unprecedented growth in domestic and municipal wastewater treatment owing to several advantages including excellent effluent quality, low sludge production, small foot print, and flexibility in future expansion [5] [10]. Application of MBR technology for industrial wastewater treatment has also gained attention because of the robustness of the process, high organic loadings and very specific biorefractory, inhibiting and difficult to treat compounds are the major characteristics of industrial waste streams that render alternative treatment techniques such as the MBR desirable. The technical features of the reactor play an important role in solid separation and biomass selection. However, it is important to highlight that industrial wastewater may heavily influence the microbial selection process within an MBR because of the presence of refractory compounds [11]; and the efficiency in the removal of the organic load depends on the type of industrial process that has been implemented and consequently on the quantity of non-biodegradable compounds. This research addresses this question by providing a comprehensive review of the studies dealing with recalcitrant industrial wastewater treatment by MBR and offers unique insights into this matter.

\section{Background}

Biochemical, mainly fermentation engineering, which includes the main waste water produced drainage, drainage aid process, rinse water and domestic sewage. Which is the largest amount of water auxiliary drainage process, COD is a direct contribution of the largest drainage process, and the wash water is important wastewater pollution, its high content of suspended matter. In addition, fermentation class biochemical wastewater ni- 
trogen content $\mathrm{N}$ ratio is high and the low, high sulfate concentrations, high color, containing microbial degradation and difficult with inhibitory substances [12]. Figure 1 showed the summery of evolution of membrane use in wastewater treatment and demonstrates the basic differences in the treatment trails.

It is necessary to investigate the performance of the MBR in removal of EDCs. Figure 2 compares the fate of two micro pollutants during treatment in a conventional and MBR process as reported in a specific study [13]. Endocrine disrupting chemicals (EDCs) are potentially harmful chemicals during wastewater reclamation. Bisphenola (BPA) is a typical EDC. It is used to synthesize polycarbonates and epoxy resins, flame retardants, and other specialty products. Furthermore BPA is applied as a constituent of dental sealants, as developing agent in the coating of thermal papers and as an anti-oxidant in the production of plasticizers and processing polyvinyl chloride. BPA removal using a submerged membrane bioreactor (MBR) was investigated by [14]. These results suggested that biodegradation dominated the BPA removal process. [15] studied the suitability of MBRs with regard to the elimination of estrogenic trace contaminants for Municipal wastewater treatment and landfill leachate treatment. Investigations of phase distributions of the trace contaminants were conducted. A significantly higher concentration appeared in the supernatant compared to the permeate concentration. They concluded that the ultrafiltration membrane was able to partly remove the macro-molecular DOC of the wastewater, while micro pollutants tended to adsorb and associate with these removed macromolecules. [13] operated a conventional biological wastewater treatment plant (BWWTP) and a membrane bio-reactor (MBR) to treat municipal wastewater. Additionally, the effluents were treated with ozone (O3). Reduction of Chemical Oxygen Demand (COD) was observed with $95 \% \pm 2 \%$. The elimination achieved without applying ozone were $>98$ or $97.8 \%$ for 4 -NP and BPA in MBR treatment and $>98$ and $91.6 \%$ under conventional treatment. Mass balance proved biodegradation as the main elimination mechanism for 4-NP and BPA in both treatment processes. In a study by [16] a pilot scale MBR was more effective at removing cholesterol, coprostanol, stigmastanol, estrogenic species (E1, EE2), and BPA to low ng/L levels than a full scale conventional activated sludge plant receiving the same wastewater. The authors opined that the lower effluent concentrations achieved by the MBR may be a function of the membrane or the increased SRT. Yeast estrogen screen (YES) bioassay and liquid chromatography-mass spectrum-mass spectrum (LC-MS-MS) analysis were performed by [17] to investigate the fate of active and potential endocrine disrupting compounds in 3 pilot-scale and 2 lab-scale membrane bioreactor (MBR) systems. The amounts of adsorbed estrogens per kg dry mass was relatively low, due to short hydraulic retention time and high mixed liquor suspended solids in MBRs, compared to that in STPs. [18] conducted investigations to determine the efficiency of various membranes for the removal of endocrine disruptors, pharmaceuticals, and personal care products. Eight pharmaceuticals, two polycyclic musk fragrances and nine endocrine disrupting chemicals were analyzed by [19] in several waste water treatment plants (WWTPs). The operation of WWTPs with SRTs suitable for nitrogen removal (SRT 4 - 10 days at 10C) also increases the removal potential regarding selected micro pollutants. No differences in treatment efficiencies were detected between the two treatment techniques. As in conventional WWTP also the removal potential of MBRs depends on the SRT. Ultrafiltration

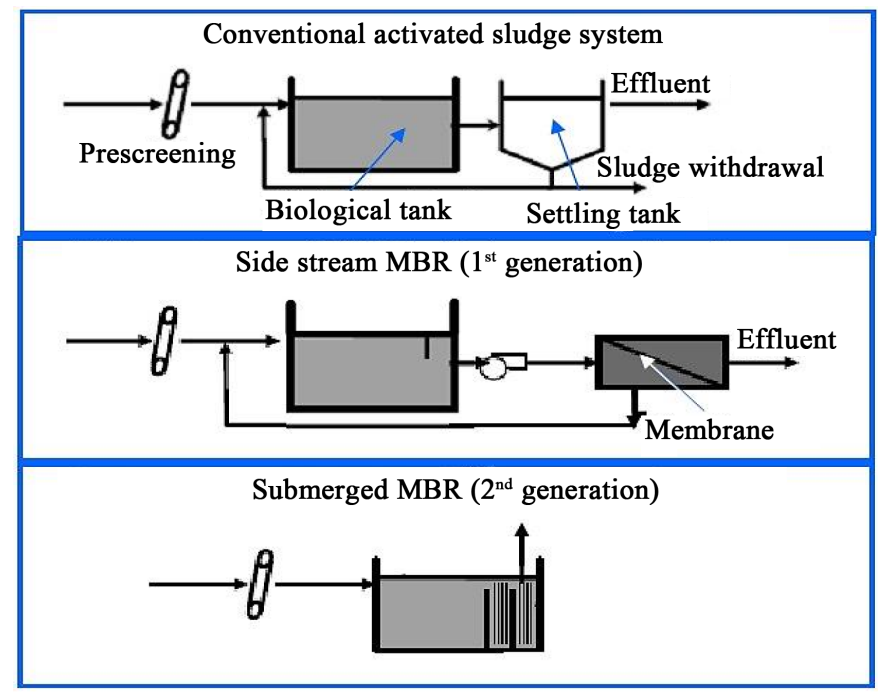

Figure 1. Evolution of membrane use in conjunction with bioreactor. 


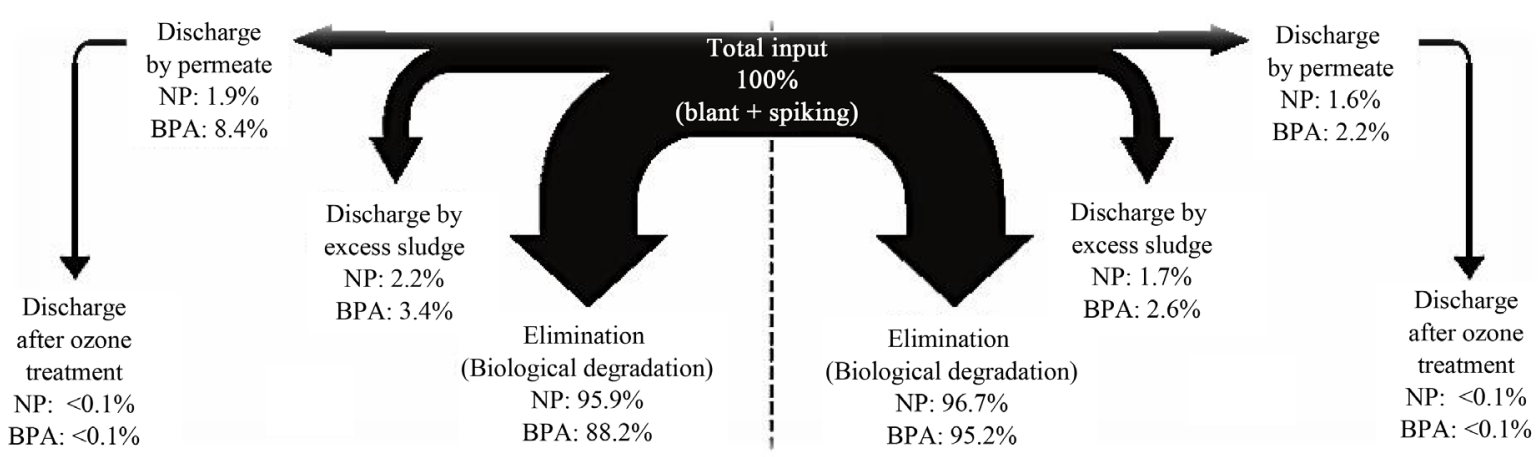

(a)

(b)

Figure 2. Mass flow chart demonstrating the fate of two micropollutants [4-nonylphenol (NP) and bisphenol A (BPA)] during treatment by (a) conventional, (b) MBR process, and after subsequent $\mathrm{O}_{3}$ treatment steps.

membranes do not allow any additional detention of the investigated substances due to size exclusion. However, MBRs achieve a high SRT within a compact reactor. Nonylphenol polyehtoxylates were removed in higher extend in very low-loaded conventional WWTPs, due to variations of redox conditions, necessary for the degradation of those compounds. [20] conducted a pilot-scale test with a two-phase anaerobic digestion (TPAD) system and a subsequent membrane bioreactor (MBR) treating chemical synthesis-based pharmaceutical wastewater. The $\mathrm{pH}$ of the MBR effluent was found in a narrow range of 6.8 - 7.6, indicating that the MBR effluent can be directly discharged into natural waters. [21] studied the potential of a lab-scale membrane bioreactor (MBR) to remove polar pollutants from municipal wastewater for industrial and household chemicals over a period of 22 months parallel to a conventional activated sludge (CAS) treatment. For half of the compounds, such as benzotriazole, 5-tolyltriazole (5-TTri), benzothiazole-2-sulfonate and 1,6-naphthalene disulfonate (1,6-NDSA), removal by MBR was significantly better than in CAS, while no improvement was recorded for the other half (1,5-NDSA, 1,3-NDSA, 4-TTri and naphthalene-1-sulfonate). The influence of operational conditions on trace pollutant removal by MBR was studied but no significant effects were found for variation of hydraulic retention time (7 h - $14 \mathrm{~h}$ ) and sludge retention time (26 d - $102 \mathrm{~d}$ ), suggesting that the lowest values selected have already been high enough for good removal. However, for most compounds of intermediate removal in CAS treatment (15\% - 80\%), among them pharmaceuticals, personal care products and industrial chemicals, the MBR is clearly superior and reduces the effluent concentration by $20 \%$ - 50\%. The fate of two differently labelled radioactive forms of 17-ethinylestradiol (EE2) in a laboratory-scale MBR was studied by [22]. The same metabolite pattern in the radio chromatograms for the two different labeling protocols led to the assumption that the elimination pathway does not involve the removal of the ethinyl group from EE2 molecule. [23] studied the biodegradation of selected non-adsorbing persistent polar pollutants (P3) during wastewater (WW) treatment by comparing a lab-scale membrane bioreactor (MBR) running in parallel to activated sludge treatment (AST). The application of such an MBR optimized in terms of sludge retention time may lead to a reduction of these P3 in the water cycle. [24] studied the ability of submerged MBRs to remove pharmaceutically active compounds (PhACs). The degradation of three estrogens, two endocrine disruptors and ten pharmaceutical substances in a membrane separation bioreactor was experimentally examined by [25]. The additional removal by the membrane was increased with the time elapsed, though the removal was not significantly high for the relatively hydrophilic compounds. The elimination of 14 pharmaceuticals, 6 hormones, 2 antibiotics, 3 personal care products (PCPs), and 1 flame retardant chemical during drinking water and wastewater treatment processes at full- and pilot-scale was investigated by [26]. However, the results showed that MBR treatment did not decrease the concentration of erythromycin, TCEP, trimethoprim, naproxen, diclofenac, and carbamazepine. [27] reported on the performances of full-scale conventional activated sludge (CAS) treatment and two pilot-scale membrane bioreactors (MBRs) in eliminating various pharmaceutically active compounds (PhACs) belonging to different therapeutic groups and with diverse physico-chemical properties. Both aqueous and solid phases were analysed for the presence of 31 pharmaceuticals included in the analytical method. Out of the 26 pharmaceutical residues passing through the WWTP, 20 were ultimately detected in the treated sludge that is further applied on farmland. The dynamics of 12 micropollutants in a membrane bioreactor (MBR) was studied when treating synthetic sewage by [28]. The selected substances corresponded to different therapeutic groups such as antiepileptic (carbamaze- 
pine), tranquillizers (diazepam), analgesics (ibuprofen, naproxen, diclofenac), antibiotics (roxithromycin, erythromycin, sulfamethoxazole, rimethoprim) and three polycyclic musk fragrances (galaxolide, tonalide, celestolide). These micropollutants were spiked into the synthetic wastewater fed to the reactor at environmentally relevant concentrations ranging from 10 to $20 \mu \mathrm{g} / \mathrm{L}$. The MBR was operated at a sludge retention time (SRT) of 44 - 72 days, since a high value of this parameter is considered as crucial removal of these micro pollutants. Under these conditions, different fates are observed depending on pharmaceutical and personal care products (PPCPs) characteristics. Hydrophobic organic substances, like musk fragrances, are partially sorbed onto the sludge. This explains the partial removal observed in the reactor, with an overall efficiency around 50\%. The biodegradation of selected priority acidic pesticides MCPP, MCPA, 2,4-D, 2,4-DP and bent zone and the acidic pharmaceutical diclofenac was investigated using a membrane bioreactor (MBR) and a fixed-bed bioreactor (FBBR) by [29]. The elimination of sulfonamides, macrolides and trimethoprim from raw wastewater was investigated in several municipal wastewater treatment plants by [30]. A pilot-scale study on pharmaceutical wastewater treatment by a membrane bioreactor (MBR) process in southern Taiwan was presented in a paper by [31]. The effluent did not contain any suspended solids. The results indicated that the MBR system has potential as a means of treating high-strength and fluctuating strength wastewater with consistent performance. [32] harvested biomass from a membrane bioreactor (MBR) and a sequencing batch reactor (SBR), and conducted sorption experiments over a range of temperatures. Sorption of 17-ethinylestradiol (EE2) to activated sludge was spontaneous $\mathrm{G}$ values were between -16 and $-11 \mathrm{KJ} / \mathrm{mol}$ ), enthalpy-driven ( $\mathrm{H}$ values were $-37 \mathrm{KJ} / \mathrm{mol}(\mathrm{MBR})$ and $-48 \mathrm{KJ} / \mathrm{mol}(\mathrm{SBR})$ ), and entropy-retarded S values were -74 (MBR) and -119 J/mol/K (SBR)). Although EE2 is nonpolar, hydrophobic interactions were not dominant driving forces. Results suggested that sorption is an important mechanism for removal of 17-ethinylestradiol (EE2) in biological wastewater treatment. [33] operated a membrane bioreactor (MBR) and a conventional bioreactor (CBR) under various conditions to assess the biomass characteristics and evaluate the ensuing effects on the partitioning and sorption hysteresis of 17-ethinylestradiol (EE2). When the biomass was grown without nitrogen limitation, the biomass mean particle size had a dramatic effect on the observed partitioning coefficient (Kd) and on sorption hysteresis index (HI). MBR Kd (0.33 - 0.57 L/g) values were equal to or larger than those of the CBR $(0.25-0.33 \mathrm{~L} / \mathrm{g})$. In a review of the factors influencing the removal of organic micro pollutants from wastewater, [34] concluded that sorption and biodegradation are the dominant removal processes in CTP and in MBR, which are influenced by operation conditions like sludge retention time (SRT), biomass concentration, temperature, $\mathrm{pH}$ value, dominant class of micro pollutants, etc. Hydrophobic compounds (NP, EE2, etc.) can be removed from the influent via adsorption to the sludge particles present in the system... Another two textile dyeing degradation bacteria, Paenibacillus azoreducens and Bacillus sp., as predominant bacteria in MBR sludge, were also observed. [35] tested the post-treatment of secondary wastewater (80\% textile, 20\% municipal) on a pilot scale low-pressure reverse osmosis (RO) module, to produce a polished effluent to be recycled into the textile factories. On account of the stability, however, the MBR permeate seemed to allow for a more regular and constant operation of the RO module, with a lower decrease in the specific flux against time. [36] tested a pilot plant membrane bioreactor in parallel with a full-scale activated sludge wastewater treatment plant fed on the wastewater from a textile factory. Compared to the existing extended aeration WWTP, the pilot MBR made it possible to obtain higher COD removal and color abatement, besides much higher removal efficiency for suspended solids and microorganisms. [37] ran a pilot MBR plant in parallel to one existing WWTP (activated sludge + clariflocculation + ozonation) for the treatment of textile wastewater (Figure 3). Paenibacillus azoreducens and Bacillus sp., as predominant bacteria in MBR sludge, were also observed. [38] tested the post-treatment of secondary wastewater ( $80 \%$ textile, $20 \%$ municipal) on a pilot scale low-pressure reverse osmosis (RO) module, to produce a polished effluent to be recycled into the textile factories. MBR and coagulation plus dual media filtration ensured that SDI values are obtained which are suitable for the feed of the low-pressure RO module. On account of the stability, however, the MBR permeate seemed to allow for a more regular and constant operation of the RO module, with a lower decrease in the specific flux against time. [36] tested a pilot plant membrane bioreactor in parallel with a full-scale activated sludge wastewater treatment plant fed on the wastewater from a textile factory. Compared to the existing extended aeration WWTP, the pilot MBR made it possible to obtain higher COD removal and color abatement, besides much higher removal efficiency for suspended solids and microorganisms. On average, removal efficiency of the pilot plant (93\% for COD, and over 99\% for total suspended solids) was higher than that of the WWTP. Color was removed as in the WWTP. Anionic surfactants removal of pilot plant was lower than that of the WWTP (90.5\% and 93.2\% respectively), while the BiAS removal was higher in the pilot plant (98.2 vs. 97.1). [39] carried out 

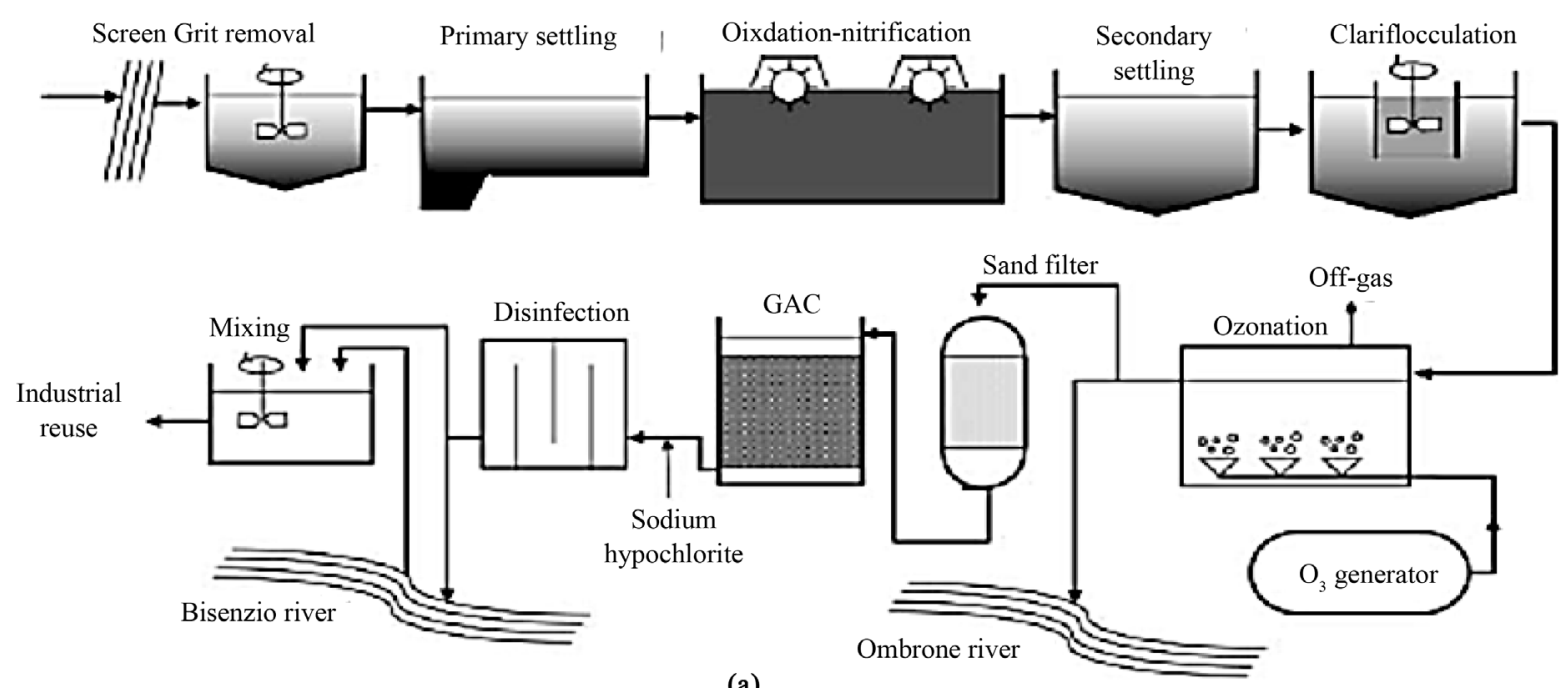

(a)

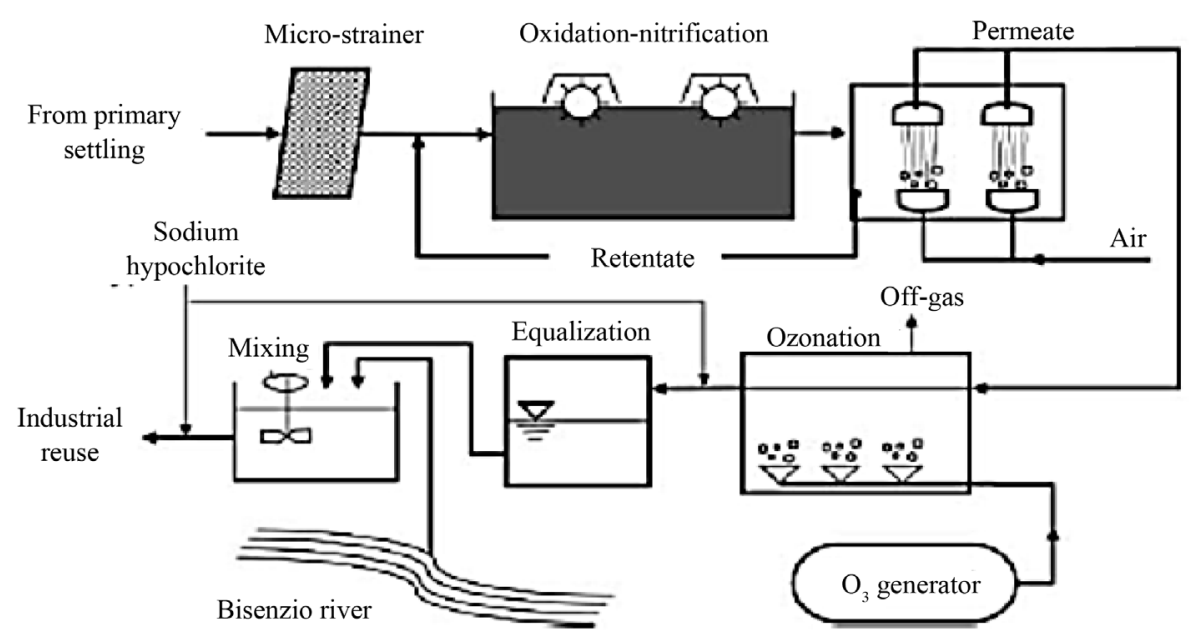

(b)

Figure 3. Schematic of two textile wastewater treatment options (a) Conventional process-based elaborate treatment trail; (b) MBR-based more compact treatment scheme.

another experimental study in order to evaluate the feasibility of upgrading a conventional activated sludge WWTP treating municipal and textile wastewaters to a membrane bioreactor(MBR).The biomass retention in the MBR reactor allowed heterotrophic bacteria growth without the need to add nutrients. [40] investigated the capability of MBR to achieve a water quality meeting reuse criteria. As most of the biodegradation of dye generally takes place at very low oxygen levels, unlike a conventional MBR operated at aerobic condition, anoxic or anaerobic conditions are required for an MBR for dye wastewater treatment. Accordingly, [41] studied an anoxic-aerobic MBR sequence for dye wastewater treatment. The treatment efficiencies of COD and the dye between aerobic and anoxic MBR were compared. A laboratory-scale membrane bioreactor (MBR) witha gravity drain was tested [42] for dyeing and printing wastewater treatment from a wool mill. Results showed that excellent effluent quality could meet the reuse water standard in China. [43] studied the design and start up a new, innovative, integrated process using membrane technology for wastewater reuse on a large scale in the Klingelmeyer laundry, Germany. The MBR permeate provides a water quality that can be used as washing water since it fully meets the requirements of the washing process. [44] developed for a specific textile finishing company strategies for water recycling and recovery of valuable chemicals. As the oxidation process is performed by specialized bacteria, selection of an appropriate microbial community is fundamental for obtaining a good yield. [45] explored an MBR in this context. Finally, the titrimetric (pH-stat, DO-stat) tests showed similar values of the ki- 
netic parameters of the nitrifies both in MBR and CASP sludge. [46] used an MBR during 120 days for treating two different wastewaters with different characteristics. A drop in the oxygen transfer efficiency was observed when the system operated with biomass concentrations above $8 \mathrm{~g}$ VSS/L. [47] carried out experiments to ascertain the role of tannins in the treatment of vegetable tanning wastewater with MBR and CASP. The removal of phenols, which can be associated with the presence of tannins, did not differ greatly between the two. Bench scale membrane bioreactors were operated by [48] to investigate the treatment efficiency of tannery wastewater with high organic and nitrogen contents and the optimum operating conditions were derived. Generation of leachate occurs when moisture enters the refuse in a landfill, dissolves the contaminants into liquid phase and becomes sufficient to initiate a liquid flow. Leachate varies from one landfill to another with fluctuations that depend on short and long-terms due to variations in climate, hydrogeology and waste composition [49]. Due to this, improvements in landfill engineering are aimed at reducing leachate production, collection and treatment prior to discharge [50]. Such process schemes generally comprise some combination of biological and physical and/or chemical treatment with key operational determinants being organic loading rate and the related hydraulic retention time. In view of the high strength of the landfill leachate, [51] utilized an aerobic thermophilic membrane bioreactor (MBR) for treating raw landfill leachate from two landfill sites in Thailand. At a hydraulic retention time (HRT) of 24 hrs the COD removal rate increased from an average value of $62 \%$ - 79\% while ammonia removal efficiency decreased from $75 \%$ to $60 \%$ with gradual increase in BOD. Furthermore, a high BOD removal efficiency (97\% - 99\%) was also observed. [52] stipulated that ammonia removal phenomenon in thermophilic condition is governed by temperature, mixing and $\mathrm{pH}$, and inhibition of biological nitrification occurs at temperatures greater than 43C. Although the ammonia removal efficiency dropped with increasing BOD/COD ratio, in view of the substantial COD removal this system appeared interesting. [53] treated landfill leachate from a composting field of a Finnish municipal waste landfill with sequencing batch reactor (SBR) and a submerged membrane bioreactor (MBR) fed batch-wise. Considerably long HRT (SBR $=4 \mathrm{~d}, \mathrm{MBR}=9 \mathrm{~d}$ ) and reasonable solids retention times (SBR $=10-40 \mathrm{~d}, \mathrm{MBR}=35-60 \mathrm{~d}$ ) were applied. In SBR, suspended solids concentration in effluent was up to $89 \%$ smaller than influent suspended solids concentration. However, sometimes bulking reduced the efficiency.

However, the sludge was escaping from the SBR unit whenever the process was disturbed and thus quite high suspended solids, BOD7, and phosphorus concentrations were observed. MBR effluent was significantly better in quality and had lower variations. [54] presented a review of quality and biological treatment of landfill leachate. They showed that conventional $e x$-situ treatment normally demands multistage process treatment schemes, which may encompass both aerobic and anaerobic technologies alongside chemical precipitation and/or oxidation. MBR-based treatment schemes appear to achieve greater COD removal, a mean of around $80 \%$ across all installations, for less biotreatable feed waters $(\mathrm{BOD} / \mathrm{COD}=0.03-0.16)$, than conventional systems which achieve COD removals of around 63\% at feed water BOD/COD ratios of 0.21 - 0.3 (Figure 4). In petroleum refinery, the combination of complex processes induces different wastewaters. The main processes inducing wastewaters are: storage, desalination, fractionation, thermal and catalytic cracking, reforming, polymerization, alkylation, isomerisation and solvent refining. [55] studied aerobic MBRs operating at room temperature $\left(20^{\circ} \mathrm{C}\right)$ and at lower thermophilic range $(45 \mathrm{C})$ for the treatment of dissolved air flotation (DAF) pretreated pet food wastewater. The particular wastewater was characterized by oil and grease $(\mathrm{O} \& \mathrm{G})$ concentrations as high as 6 $\mathrm{g} / \mathrm{L}$, COD of $51 \mathrm{~g} / \mathrm{L}$, BOD of $16 \mathrm{~g} / \mathrm{L}$ and volatile fatty acid (VFA) of $8.3 \mathrm{~g} / \mathrm{L}$. The use of a submerged membrane bioreactor for the treatment of industrial oil contaminated wastewater was investigated using microfiltration hollow fiber membranes by [56]. The membrane bioreactor worked with a hydrocarbon concentration ranging from 600 to $1500 \mathrm{mg} / \mathrm{L}$ in a sub-critical flux regime. The sludge concentration ranged from $14 \mathrm{~g} / \mathrm{L}$ to $28 \mathrm{~g} / \mathrm{L}$. The MBR was able to treat wastewater with high removal efficiency (about 98\%), under low hydraulic retention time (about $10 \mathrm{~h}$ ) and high biomass concentration. The use of a crossflow membrane bioreactor (CF-MBR) in treating wastewater discharged by a petroleum refinery was investigated by [57]. The performance of the CF-MBR process was evaluated at MLSS concentrations of 5000 and $3000 \mathrm{mg} / \mathrm{l}$. The process performance was measured in terms of the hydraulic efficiency as well as the COD removal efficiency. The results of the investigation showed that a COD removal efficiency of more than 93\% was obtained at both MLSS values. The study also showed that hydraulic retention time did not have a significant effect on the system's performance. [58] undertook an experimental study of olive mill wastewater (OMW) treatment in an external ceramic membrane bioreactor (MBR). OMW is one of the most contaminated effluents. Table 1 compares COD removal during olive mill wastewater treatment by different processes. Phenol and its derivatives are widely used as raw materials in 


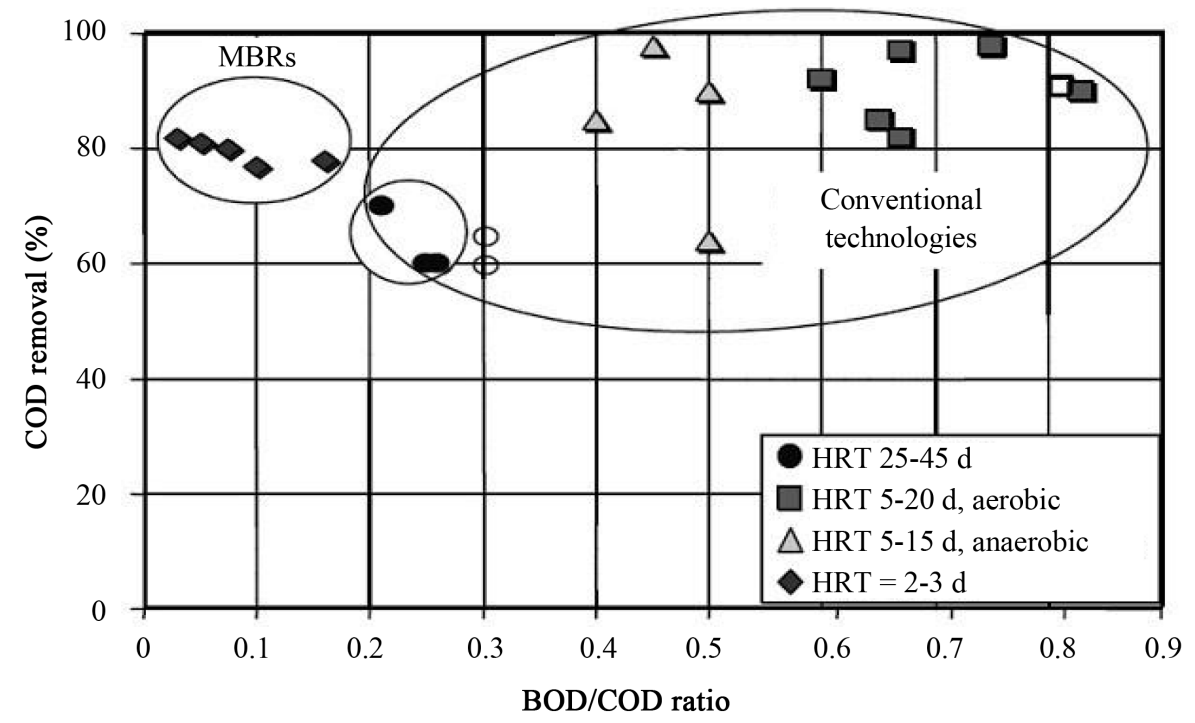

Figure 4. COD removal vs leachate BOD/COD ratio for different HRT ranges, full-scale plant; open data points refer to twostage processes, hatched areas represent comparable data.

Table 1. COD removal during olive mill waste water treatment by different process.

\begin{tabular}{|c|c|c|c|c|}
\hline Process & $\begin{array}{l}\text { Phenol inlet } \\
\left(\mathrm{mg} \cdot \mathrm{l}^{-1}\right)\end{array}$ & $\begin{array}{l}\text { Phenol removal } \\
\text { (g) }\end{array}$ & COD Inlet $\left(\mathrm{mg} \cdot \mathrm{I}^{-1}\right)$ & $\begin{array}{c}\text { COD removal } \\
\text { (g) }\end{array}$ \\
\hline Electrochemical & 1520 & $>90$ & $1475-6545$ & $35-15$ \\
\hline Electro-coagulation & nd & nd & 4850 & 52 \\
\hline UASB reactors & nd & nd & 5000 & 70 \\
\hline CAC reactors & $720-1420$ & $70-74$ & $10,256-26,211$ & $32-65$ \\
\hline Fungal Laccase & 3700 & 65 & 43,000 & 5.3 \\
\hline Pleurotus & 3400 & $69-76$ & 140,000 & nd \\
\hline MBR & 5410 & $>92$ & $1500-5300$ & $81-37$ \\
\hline
\end{tabular}

the petrochemical industry and in oil refineries. A phenolic compound due to their high toxicity inhibits microorganisms or even eliminates them from municipal biological wastewater treatment plants. [59] showed the feasibility of the MBR treatment of a synthetic effluent containing a large amount of phenol. Using a biomass acclimated to phenol degradation, the critical conditions of membrane separation were determined: TMP $=100$ $\mathrm{kPa}$ (1 bar) and $\mathrm{v}=5 \mathrm{~ms}^{-1}$. The membrane bioreactor process was evaluated in terms of membrane performance and biological degradation. The experiment of phenol degradation proved the effectiveness of the step of activated sludge acclimation, since a steady state was reached in a few hours. No phenol was detected in the permeate and a large quantity of phenol $\left(50 \mathrm{~g} \cdot\right.$ day $\left.^{-1}\right)$ was degraded. The absence of suspended matter, the removal of a substantial amount of phenol and a good performance on organic substance removal shows the excellent performances of MBR. [60] evaluated practical possibilities to upgrade existing wastewater treatment facilities to MBR technology. The effluent was of high quality and could be considered for reuse in paper mill and food production. Trials in a MBR with a high activated sludge concentration of up to $48 \mathrm{~g} / 1$, showed that oilywastewater also containing surfactants was biodegraded with high efficiency, this study showed the superiority of MBR in comparison to plain filtration (Table 2) [61]. To extend the service life and to improve the quality of degreasing solutions from surface refining processes in the metal working industry a process based on a membrane bioreactor (MBR) with submerged multi-channel fiat sheet ceramic membranes was developed by [62]. Compared to conventional (“open”) biological regeneration, a fivefold increase in volumetric biodegradation rate was achieved due to the higher biomass concentration. In order to develop full scale process and design information, [63], conducted field pilot studies for several months. These pilot studies involved assessing system 
Table 2. Comparison of Operation parameters between industrial-scale applied ultrafilteration systems treating oil-contaminated waste water from machine factoring and the membrane biorecator system.

\begin{tabular}{ccc}
\hline & Membrane bioreactor & Membrane application \\
\hline COD $\left(\mathbf{m g} \cdot \mathbf{l}^{-\mathbf{1}}\right)$ & $129-131$ & 373 \\
Oil (ppm) & $0.036-0.35$ & 85.6 \\
COD removeal effieciency (\%) & 97 & 99.2 \\
Oil removal effieciency (\%) & 99.9 & 1 \\
\hline
\end{tabular}

performance and developing system design information in the treatment of wastewaters from metalworking automotive plants. The results of the pilot studies provided the basis for the design of a full scaleemonstration MBR system for treatment of industrial oily wastewaters. The feasibility and the treatment efficiency of treating acrylonitrile-butadiene-styrene (ABS) industrial wastewater by an aerated submerged membrane bioreactor (ASMBR) were investigated [64]. Two lab scale wastewater treatment plants treating hospital wastewater in parallel were compared by [65] in terms of performance characteristics. One plant consisted of a conventional activated sludge system (CAS) and comprised an anoxic and aerobic compartment followed by a settling tank with recycle loop. The second pilot plant was a plate membrane bioreactor (MBR). The CAS system typically decreased bacterial groups for about 1 log unit, whereas the MBR decreased these groups for about 3 log units. Enterococci were decreased below the detection limit in the MBR and indicator organisms such as fecal coliforms were decreased for $1.4 \log$ units in the CAS system compared to a 3.6 log removal in the MBR.

[66] reported an industrial estate Shanghai's coagulation sedimentation process-MBR examples of proprietary industrial wastewater treatment works in generated wastewater quality, quantity volatility than large, high chrome and suspended solids containing refractory material. The design of water for $120 \mathrm{~m}^{3} \cdot \mathrm{D}^{-1}$, The COD concentration of 3000 - $6000 \mathrm{mg} / \mathrm{L}$. engineering since December 2006. The effect of steady production process, the effluent COD concentration were $100 \mathrm{mg} / \mathrm{L}$, the removal rate $98 \%$, all the other indicators are to meet emission standards. Stable operation of the process after handling charges with moderate to $1.76 \mathrm{yuan} \cdot \mathrm{m}^{-3}$.

[67] summarized the potential applications of the MBR technology for the treatment of wastewater from agricultural sources. Hence to fully exploit the augmented MBR system, the microbial population structure, dynamics and the survival of the added microorganisms should be better understood. [68] studied the removal performances of Bromoamineacid (1-amino-4-bromoanthraquinone-2-sulfonic acid, BAA) which is widely used in synthesis of anthraquinone dyes and also the microbial population changes ina laboratory-scale membrane bioreactor (MBR) augmented with Sphingomonas xenophaga QYY. However, with increase of influent BAA concentration, the removal ratio was decreased. Also, the dynamic and structure of bacterial populations were not kept at a normal level. On the other hand, the augmented MBR showed higher removals (more than 90\% and 50\% color and COD removals, respectively) (Figure 5). The augmented MBR possessed relatively stable treatment abilities, in which the introduced strain QYY could be persistent and co-exist well with the indigenous populations. [61] reported efficient and stable atrazine removal after a start-up period in a membrane bioreactor (MBR) bioaugmented with genetically engineered microorganism (GEM). Possibly high biomass concentrations in the MBR stimulated transfer of the clcelement from strain BN210 to autochthonous bacteria. Also, autochthonous 3CBA degrading bacteria might benefit from specific conditions in the MBR. [69] investigated biological treatment of medium-age landfill leachate in a membrane bioreactor operated with mixed yeast culture termed as yeast based membrane bioreactor (YMBR). This superior performance of the YMBR could be due to the structure of yeast cells which are larger in size as well as reduced soluble extracellular polymeric substances (EPS) production, which are the main cause of membrane biofouling. [70] developed a submerged membrane bioreactor containing a mixed microbial community dominated by the white-rot fungus Coriolis versicolored for the treatment of textile dye wastewater. Under controlled temperature $\left(29^{\circ} \mathrm{C} \pm 1^{\circ} \mathrm{C}\right)$ and $\mathrm{pH}(4.5 \pm 0.2)$, and applied HRT of $15 \mathrm{~h}$, the reactor accomplished around 97\% TOC and 99\% color removal from the synthetic wastewater (TOC $=2 \mathrm{~g} / \mathrm{L}$; dye $=100 \mathrm{mg} / \mathrm{L}$ ) for a prolonged period of observation. The addition of adsorbents into a biological treatment system allows removing various toxic or non-biodegradable organic substances from the wastewaters and reduces their toxic effects on microorganisms [71]. Slowly biodegradable or toxic compounds are adsorbed and thereby their residence time within the reactor increases, which gives appropriate time for biodegradation [71]. Figure 6 [72] illustrates the hybrid PAC-membrane-biodegradation concept [73]. Ex- 


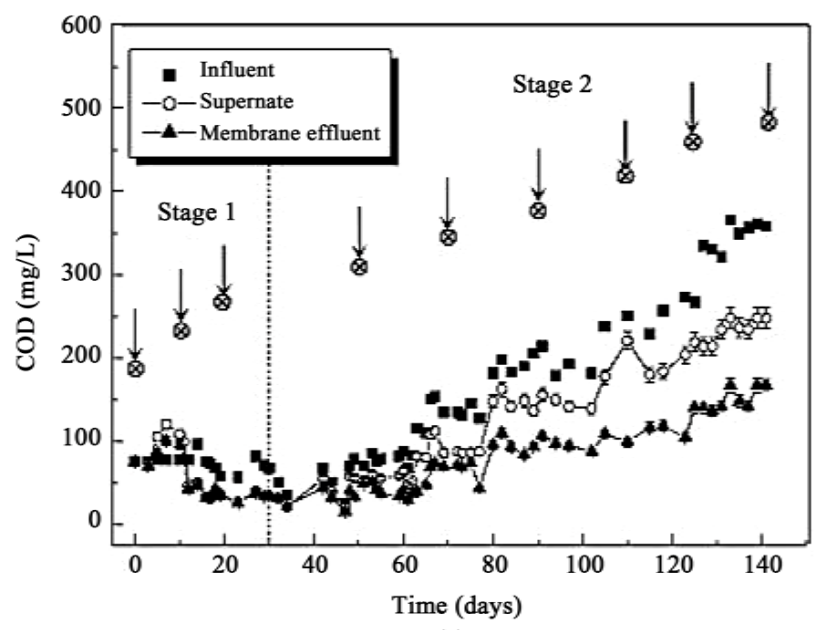

(a)

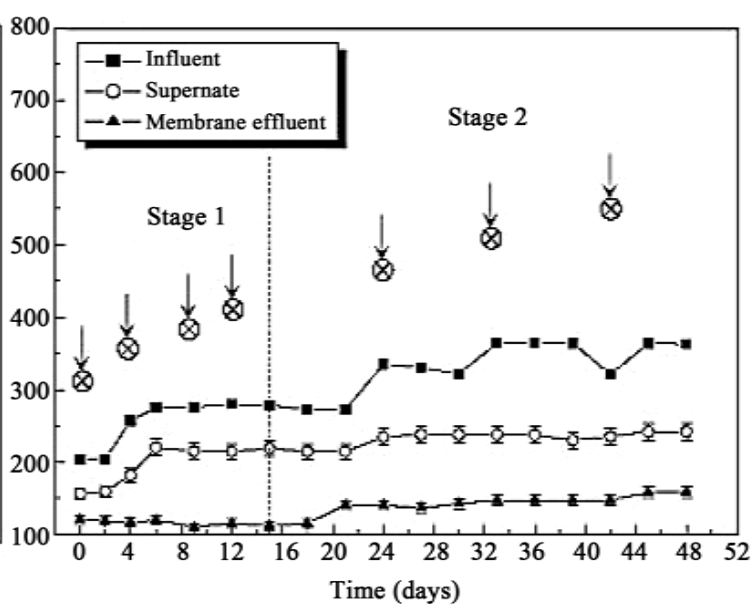

(b)

Figure 5. COD removal from wastewater containing the recalcitrant compound Bromoamine acid (BAA) in a non-augmented (a) and bio-augmented (b) MBR system.

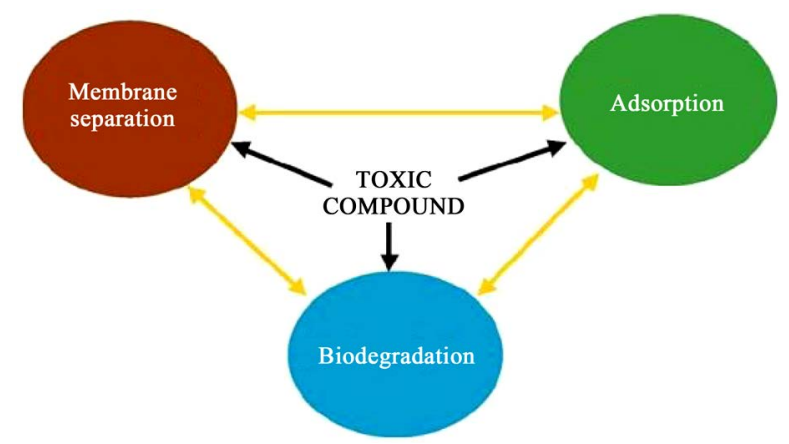

Figure 6. Schematic of hybrid adsorption-membrane separation-biodegradation process for toxic compound degradation.

plored a PAC-added membrane-coupled fungi reactor for textile dye wastewater treatment. Simultaneous PAC adsorption within fungi MBR thus resulted in multiple advantages including adsorption of dye and prevention of enzyme washout, eventually leading to enhanced dye degradation. [74] operated a pilot scale membrane bioreactor (MBR) with the addition of powdered activated carbon (PAC) to analyze improvements in effluent quality and the filtration process. The filtration process was evaluated in terms of sludge filterability, fouling rate and fouling reversibility. The fouling rate decreased with an increasing PAC concentration and showed complete reversibility both in presence and in absence of PAC. [72] compared a membrane bioreactor (MBR) and a hybrid membrane bioreactor (HMBR) coupling membrane separation, biological activity and adsorption on powdered activated carbon (PAC) in order to remove a toxic compound. Toxic injection inhibits the biological activity in the MBR whereas the biological activity is maintained in the HMBR, with a biodegradation of the toxic compound after an acclimation period. [75] investigated the treatability of phenolic compounds by using two membrane bioreactor systems, namely: activated sludge coupled with MBR (AS-MBR) and biological granular activated carbon coupled with MBR (BAC-MBR). The relationship between sludge properties and EPS components revealed that settle ability had no direct correlation with EPS, though it was better correlated to protein/ carbohydrate ratios. Adding iron salt or iron hydroxide to sludge mixed liquor in an aeration tank of a conventional activated sludge processes (bio ferric process) can simultaneously improve the sludge's filterability and enhance the system's treatment capacity. In view of this, [76] added $\mathrm{Fe}(\mathrm{OH})_{3}$ to a submerged membrane bioreactor (SMBR) to enhance the removal efficiency and to mitigate membrane fouling.

\section{Conclusions}

This study concluded the attraction of MBR system. The applications of MBR are necessary for long biological 
solids retention times, physical retention and subsequent hydrolysis to achieve the biological degradation of pollutants. The removal rates differ from one compound to the other and depend on the physico-chemical characteristics of the xenobiotic. High MLSS and long SRT can enhance biodegradation by development of special microbes but sometimes can get the more significant results due to adsorption on biomass, retention by membrane and subsequent biodegradation. Bio-augmentation or addition of PAC has to enhance removal. The main superiority of the MBR is compatibility with such additional measures over the conventional wastewater systems. The implementation of a biological stages in MBR enhances membrane permeate quality due to the degradation of the pollutants due to high biomass concentration in combination with the filtration effect, which increases the actual concentration of the pollutants in the bioreactor and bio-availability lead to enhanced biodegradation efficiencies, while biodegradation leads to lower actual concentrations of the pollutants in the feed stream of the filtration unit. The main advantage of the membrane bioreactor is that the major part of the pollutants is mineralized. New developments in this field are expected to lead to excellent solutions to treatment of recalcitrant industrial wastewater.

\section{References}

[1] Fernando, S.G.E. (2011) The Book: Waste Water Treatment and Reutilization. Intech Open Access Publishers.

[2] Ming, Y. and De-Sheng, W. (2010) Experimental Study of Antibiotic Wastewater. Journal of MBR Treatment. Environmental Protection and Recycling Economy, 9, 54-55.

[3] Judd, S. (2010) The MBR Book: Principles and Applications of Membrane Bioreactors for Water and Wastewater Treatment. Elsevier, UK.

[4] Jianwen, Bin, S., Hang, F.L., et al. (2010) Test Membrane Bioreactor Wastewater Treatment Cephalosporin Pharmaceutical Study. Environmental Engineering, 28, 65-66.

[5] Visvanathan, C., Aim, R.B. and Parameshwaran, K. (2000) Membrane Separation Bioreactors for Wastewater Treatment. Critical Reviews in Environmental Science and Technology, 30, 1-48. http://dx.doi.org/10.1080/10643380091184165

[6] Liaozhi, M. (2010) MBR Process of Fermentation Class Pharmaceutical wastewater Treatment Pilot Study. Journal of China Water \& Wastewater, 26, 131-133.

[7] Wang, L.K. and Menon, R. (2011) Treatment of Industrial Effluents, Municipal Wastes, and Potable Water by Membrane Bioreactors. In: Wang, L.K., Chen, J.P., Hung, Y.-T. and Shammas, N.K., Eds., Membrane and Desalination Technologies, Humana Press, USA, 201-236.

http://dx.doi.org/10.1007/978-1-59745-278-6_5

[8] Ivanovic, I. (2011) Application of Biofilm Membrane Bioreactor (BF-MBR) for Municipal Wastewater Treatment Doctoral Dissertation, Norwegian University of Science and Technology, Trondheim.

[9] Zheng, C.L., Zhao, L., Zhou, X.B., Fu, Z.M. and Li, A. (2013) Treatment Technologies for Organic Wastewater. INTECH Open Access Publisher, China. http://dx.doi.org/10.5772/52665

[10] Yang, W., Cicek, N. and Ilg, J. (2006) State-of-the-Art of Membrane Bioreactors: Worldwide Research and Commercial Applications in North America. Journal of Membrane Science, 270, 201-211. http://dx.doi.org/10.1016/j.memsci.2005.07.010

[11] Klinkow, N., Oleksy-Frenzel, J. and Jekel, M. (1998) Toxicity-Directed Fractionation of Organic Compounds in Tannery Wastewater with Regard to Their Molecular Weight and Polarity. Water Research, 32, 2583-2592. http://dx.doi.org/10.1016/S0043-1354(98)00017-7

[12] Wei, Z., Jun, C.L. and Yao, C.H. (2010) Contact Oxidation-Hydrolysis MBR Cephalosporin Antibiotic Treatment Chemical Synthesis Wastewater. Chemical Environmental Protection, 30, 395-399.

[13] Fr, S.H. (2006) The Elimination of the Endocrine Disrupters 4-Nonylphenol and Bisphenol A during Wastewater Treatment-Comparison of Conventional and Membrane Assisted Biological Wastewater Treatment Followed by an Ozone Treatment. Water Practice \& Technology, 1.

[14] Chen, J., Huang, X. and Lee, D. (2008) Bisphenol A Removal by a Membrane Bioreactor. Process Biochemistry, 43, 451-445. http://dx.doi.org/10.1016/j.procbio.2008.01.001

[15] Lyko, S., Wintgens, T. and Melin, T. (2005) Estrogenic Trace Contaminants in Wastewater-Possibilities of Membrane Bioreactor Technology. Desalination, 178, 95-105. http://dx.doi.org/10.1016/j.desal.2004.12.016

[16] Spring, A.J., Bagley, D.M., Andrews, R.C., Lemanik, S. and Yang, P. (2007) Removal of Endocrine Disrupting Compounds Using a Membrane Bioreactor and Disinfection. Journal of Environmental Engineering and Science, 6, 131137. http://dx.doi.org/10.1139/s06-049 
[17] Hu, J.Y., Chen, X., Tao, G. and Kekred, K. (2007) Doctrine Disrupting Compounds in Membrane Bioreactor Systems. Environmental Science Technology, 41, 4097-4102. http://dx.doi.org/10.1021/es062695v

[18] Snyder, S.A., Adham, S., Redding, A.M., Cannon, F.S., DeCarolis, J., Oppenheimer, J. and Yoon, Y. (2007) Role of Membranes and Activated Carbon in the Removal of Endocrine Disruptors and Pharmaceuticals. Desalination, 202, 156-181. http://dx.doi.org/10.1016/j.desal.2005.12.052

[19] Clara, M., Strenn, B., Gans, O., Martinez, E., Kreuzinger, N. and Kroiss, H. (2005) Removal of Selected Pharmaceuticals, Fragrances and Endocrine Disrupting Compounds in a Membrane Bioreactor and Conventional Wastewater Treatment Plants. Water Research, 39, 4797-4807. http://dx.doi.org/10.1016/j.watres.2005.09.015

[20] Chen, Z., Ren, N., Wang, A., Zhang, Z.P. and Shi, Y. (2008) A Novel Application of TPAD-MBR System to the Pilot Treatment of Chemical Synthesis-Based Pharmaceutical Wastewater. Water Research, 42, 3385-3392. http://dx.doi.org/10.1016/j.watres.2008.04.020

[21] Weiss, S. and Reemtsma, T. (2008) Membrane Bioreactors for Municipal Wastewater Treatment-A Viable Option to Reduce the Amount of Polar Pollutants Discharged into Surface Waters. Water Research, 42, 3837-3847. http://dx.doi.org/10.1016/j.watres.2008.05.019

[22] Cirja, M., Zuehlke, S., Ivashechkin, P., Hollender, J., Schäffer, A. and Corvini, P.F. (2007) Behavior of Two Differently Radiolabelled $17 \alpha$-Ethinylestradiols Continuously Applied to a Laboratory-Scale Membrane Bioreactor with Adapted Industrial Activated Sludge. Water Research, 41, 4403-4412. http://dx.doi.org/10.1016/j.watres.2007.06.022

[23] Bernhard, M., Müller, J. and Knepper, T.P. (2006) Biodegradation of Persistent Polar Pollutants in Wastewater: Comparison of an Optimised Lab-Scale Membrane Bioreactor and Activated Sludge Treatment. Water Research, 40, 34193428. http://dx.doi.org/10.1016/j.watres.2006.07.011

[24] Kimura, K., Hara, H. and Watanabe, Y. (2005) Removal of Pharmaceutical Compounds by Submerged Membrane Bioreactors (MBRs). Desalination, 178, 135-140. http://dx.doi.org/10.1016/j.desal.2004.11.033

[25] Urase, T., Kagawa, C. and Kikuta, T. (2005) Factors Affecting Removal of Pharmaceutical Substances and Estrogens in Membrane Separation Bioreactors. Desalination, 178, 107-113. http://dx.doi.org/10.1016/j.desal.2004.11.031

[26] Kim, S.D., Cho, J., Kim, I.S., Vanderford, B.J. and Snyder, S.A. (2007) Occurrence and Removal of Pharmaceuticals and Endocrine Disruptors in South Korean Surface, Drinking, and Waste Waters. Water Research, 41, 1013-1021. http://dx.doi.org/10.1016/j.watres.2006.06.034

[27] Suárez, S., Reif, R., Lema, J.M. and Omil, F. (2012) Mass Balance of Pharmaceutical and Personal Care Products in a Pilot-Scale Single-Sludge System: Influence of T. SRT and Recirculation Ratio. Chemosphere, 89, 164-171. http://dx.doi.org/10.1016/i.chemosphere.2012.05.094

[28] Radjenović, J., Petrović, M. and Barceló, D. (2009) Fate and Distribution of Pharmaceuticals in Wastewater and Sewage Sludge of the Conventional Activated Sludge (CAS) and Advanced Membrane Bioreactor (MBR) Treatment. Water Research, 43, 831-841. http://dx.doi.org/10.1016/j.watres.2008.11.043

[29] González, S., Müller, J., Petrovic, M., Barceló, D. and Knepper, T.P. (2006) Biodegradation Studies of Selected Priority Acidic Pesticides and Diclofenac in Different Bioreactors. Environmental Pollution, 144, 926-932. http://dx.doi.org/10.1016/j.envpol.2006.02.021

[30] Göbel, A., McArdell, C.S., Joss, A., Siegrist, H. and Giger, W. (2007) Fate of Sulfonamides, Macrolides, and Trimethoprim in Different Wastewater Treatment Technologies. Science of the Total Environment, 372, 361-371. http://dx.doi.org/10.1016/j.scitotenv.2006.07.039

[31] Chang, C.Y., Chang, J.S., Vigneswaran, S. and Kandasamy, J. (2008) Pharmaceutical Wastewater Treatment by Membrane Bioreactor Process-A Case Study in Southern Taiwan. Desalination, 234, 393-401. http://dx.doi.org/10.1016/j.desal.2007.09.109

[32] Xu, K., Harper, W.F. and Zhao, D. (2008) $17 \alpha$-Ethinylestradiol Sorption to Activated Sludge Biomass: Thermodynamic Properties and Reaction Mechanisms. Water Research, 42, 3146-3152. http://dx.doi.org/10.1016/j.watres.2008.03.005

[33] Yi, T. and Harper, W.F. (2007) The Effect of Biomass Characteristics on the Partitioning and Sorption Hysteresis of 17 $\alpha$-Ethinylestradiol. Water Research, 41, 1543-1553. http://dx.doi.org/10.1016/j.watres.2006.12.023

[34] Cirja, M., Ivashechkin, P., Schäffer, A. and Corvini, P.F. (2008) Factors Affecting the Removal of Organic Micropollutants from Wastewater in Conventional Treatment Plants (CTP) and Membrane Bioreactors (MBR). Reviews in Environmental Science and Bio/Technology, 7, 61-78. http://dx.doi.org/10.1007/s11157-007-9121-8

[35] Rozzi, R., Armesto, J.J., Goffinet, B., Buck, W., Massardo, F., Silander, J. and Callicott, J.B. (2008) Changing Lenses to Assess Biodiversity: Patterns of Species Richness in Sub-Antarctic Plants and Implications for Global Conservation. Frontiers in Ecology and the Environment, 6, 131-137. http://dx.doi.org/10.1890/070020

[36] Malpei, F., Bonomo, L. and Rozzi, A. (2003) Feasibility Study to Upgrade a Textile Wastewater Treatment Plant by a Hollow Fiber Membrane Bioreactor for Effluent Reuse. Water Science \& Technology, 47, 33-39. 
[37] Lubello, C. and Gori, R. (2005) Membrane Bio-Reactor for Textile Wastewater Treatment Plant Upgrading. Water Science \& Technology, 52, 91-98.

[38] Rozzi, R., Draguicevic, J.M., Arango, X., Sherriffs, M., Ippi, S., Anderson, C., Acevedo, M., McGehee, S., Plana, J., Cortés, E. and Massardo, F. (2005) Desde la cienciahacia la conservación: El programa de educación y éticaambiental del Parque Etnobotánico Omora. Revista Ambiente y Desarrollo de CIPMA, 21, 20-29.

[39] Lubello, C., Caffaz, S., Manglni, L., Santianni, D. and Caretti, C. (2007) MBR Pilot Plant for Textile Wastewater Treatment and Reuse. Water Science \& Technology, 55, 115-124. http://dx.doi.org/10.2166/wst.2007.314

[40] Brik, M., Schoeberl, P., Chamam, B., Braun, R. and Fuchs, W. (2006) Advanced Treatment of Textile Wastewater towards Reuse Using a Membrane Bioreactor. Process Biochemistry, 41, 1751-1757. http://dx.doi.org/10.1016/j.procbio.2006.03.019

[41] Yun, M.A., Yeon, K.M., Park, J.S., Lee, C.H., Chun, J. and Lim, D.J. (2006) Characterization of Biofilm Structure and Its Effect on Membrane Permeability in MBR for Dye Wastewater Treatment. Water Research, 40, 45-52. http://dx.doi.org/10.1016/j.watres.2005.10.035

[42] Zheng, X. and Liu, J. (2006) Dyeing and Printing Wastewater Treatment Using a Membrane Bioreactor with a Gravity Drain. Desalination, 190, 277-286. http://dx.doi.org/10.1016/j.desal.2005.09.008

[43] Hoinkis, J. and Panten, V. (2008) Wastewater Recycling in Laundries-From Pilot to Large-Scale Plant. Chemical Engineering and Processing: Process Intensification, 47, 1159-1164. http://dx.doi.org/10.1016/j.cep.2007.12.010

[44] Schoeberl, P., Brik, M., Braun, R. and Fuchs, W. (2005) Treatment and Recycling of Textile Wastewater-Case Study and Development of a Recycling Concept. Desalination, 171, 173-183. http://dx.doi.org/10.1016/j.desal.2004.02.105

[45] Vannini, C., Domingo, G., Marsoni, M., De Mattia, F., Labra, M., Castiglioni, S. and Bracale, M. (2011) Effects of a Complex Mixture of Therapeutic Drugs on Unicellular Algae Pseudokirchneriella subcapitata. Aquatic Toxicology, 101, 459-465. http://dx.doi.org/10.1016/j.aquatox.2010.10.011

[46] Artiga, P., Ficara, E., Malpei, F., Garrido, J.M. and Mendez, R. (2005) Treatment of Two Industrial Wastewaters in a Submerged Membrane Bioreactor. Desalination, 179, 161-169. http://dx.doi.org/10.1016/j.desal.2004.11.064

[47] Munz, G., De Angelis, D., Gori, R., Mori, G., Casarci, M. and Lubello, C. (2009) The Role of Tannins in Conventional and Membrane Treatment of Tannery Wastewater. Journal of Hazardous Materials, 164, 733-739. http://dx.doi.org/10.1016/j.jhazmat.2008.08.070

[48] Chung, Y.J., Choi, H.N., Lee, S.E. and Cho, J.B. (2004) Treatment of Tannery Wastewater with High Nitrogen Content Using Anoxic/Oxic Membrane Bio-Reactor (MBR). Journal of Environmental Science and Health, Part A: Toxic/Hazardous Substances and Environmental Engineering, 39, 1881-1890. http://dx.doi.org/10.1081/ESE-120037885

[49] Keenan, J.D., Steiner, R.L. and Fungaroli, A.A. (1984) Landfill Leachate Treatment. Journal (Water Pollution Control Federation), 56, 27-33.

[50] Farquhar, G.J. (1989) Leachate: Production and Characterization. Canadian Journal of Civil Engineering, 16, $317-325$. http://dx.doi.org/10.1139/189-057

[51] Visvanathan, C., Choudhary, M.K., Montalbo, M.T. and Jegatheesan, V. (2007) Landfill Leachate Treatment Using Thermophilic Membrane Bioreactor. Desalination. 204, 8-16. http://dx.doi.org/10.1016/j.desal.2006.02.028

[52] LaPara, T.M. and Alleman, J.E. (1999) Thermophilic Aerobic Biological Wastewater Treatment. Water Research, 33, 895-908. http://dx.doi.org/10.1016/S0043-1354(98)00282-6

[53] Laitinen, N., Luonsi, A. and Vilen, J. (2006) Landfill Leachate Treatment with Sequencing Batch Reactor and Membrane Bioreactor. Desalination, 191, 86-91. http://dx.doi.org/10.1016/j.desal.2005.08.012

[54] Alvarez-Vazquez, H., Jefferson, B. and Judd, S.J. (2004) Membrane Bioreactors vs Conventional Biological Treatment of Landfill Leachate: A Brief Review. Journal of Chemical Technology and Biotechnology, 79, 1043-1049. http://dx.doi.org/10.1002/jctb.1072

[55] Kurian, R., Acharya, C., Nakhla, G. and Bassi, A. (2005) Conventional and Thermophilic Aerobic Treatability of High Strength Oily Pet Food Wastewater Using Membrane-Coupled Bioreactors. Water Research, 39, 4299-4308. http://dx.doi.org/10.1016/j.watres.2005.08.030

[56] Bienati, B., Bottino, A., Capannelli, G. and Comite, A. (2008) Characterization and Performance of Different Types of Hollow Fibre Membranes in a Laboratory-Scale MBR for the Treatment of Industrial Wastewater. Desalination, 231, 133-140. http://dx.doi.org/10.1016/j.desal.2007.10.027

[57] Rahman, M.M. and Al-Malack, M.H. (2006) Performance of a Crossflow Membrane Bioreactor (CF-MBR) When Treating Refinery Wastewater. Desalination, 191, 16-26. http://dx.doi.org/10.1016/j.desal.2005.05.022

[58] Vannini, C., Munz, G., Mori, G., Lubello, C., Verni, F. and Petroni, G. (2008) Sulphide Oxidation to Elemental Sulphur in a Membrane Bioreactor: Performance and Characterization of the Selected Microbial Sulphur-Oxidizing Community. Systematic and Applied Microbiology, 31, 461-473. http://dx.doi.org/10.1016/j.syapm.2008.07.003 
[59] Barrios-Martinez, A., Barbot, E., Marrot, B., Moulin, P. and Roche, N. (2006) Degradation of Synthetic Phenol-Containing Wastewaters by MBR. Journal of Membrane Science, 281, 288-296. http://dx.doi.org/10.1016/j.memsci.2006.03.048

[60] Galil, N.I. and Levinsky, Y. (2007) Sustainable Reclamation and Reuse of Industrial Wastewater Including Membrane Bioreactor Technologies: Case Studies. Desalination, 202, 411-417. http://dx.doi.org/10.1016/j.desal.2005.12.081

[61] Liu, C., Huang, X. and Wang, H. (2008) Start-Up of a Membrane Bioreactor Bioaugmented with Genetically Engineered Microorganism for Enhanced Treatment of Atrazine Containing Wastewater. Desalination, 231, 12-19. http://dx.doi.org/10.1016/j.desal.2007.11.034

[62] Blöcher, C., Bunse, U., Seßler, B., Chmiel, H. and Janke, H.D. (2004) Continuous Regeneration of Degreasing Solutions from Electroplating Operations Using a Membrane Bioreactor. Desalination, 162, 315-326. http://dx.doi.org/10.1016/S0011-9164(04)00065-7

[63] Sutton, P.M., Mishra, P.N. and Crawford, P.M. (1994) Combining Biological and Physical Processes for Complete Treatment of Oily Wastewaters. International Biodeterioration \& Biodegradation, 33, 3-21. http://dx.doi.org/10.1016/0964-8305(94)90052-3

[64] Chang, J.S., Chang, C.Y., Chen, A.C., Erdei, L. and Vigneswaran, S. (2006) Long-Term Operation of Submerged Membrane Bioreactor for the Treatment of High Strength Acrylonitrile-Butadiene-Styrene (ABS) Wastewater: Effect of Hydraulic Retention Time. Desalination, 191, 45-51. http://dx.doi.org/10.1016/j.desal.2005.07.020

[65] Pauwels, B., Fru Ngwa, F., Deconinck, S. and Verstraete, W. (2006) Effluent Quality of a Conventional Activated Sludge and a Membrane Bioreactor System Treating Hospital Wastewater. Environmental Technology, 27, 395-402. http://dx.doi.org/10.1080/09593332708618651

[66] Shun, S.Y. and Fangmin, L. (2011) Coagulation and Sedimentation-MBR Pharmaceutical Wastewater Treatment Process. Journal of Water Supply and Drainage, 37, 63-64.

[67] Cicek, N. (2003) A Review of Membrane Bioreactors and Their Potential Application in the Treatment of Agricultural Wastewater. Canadian Biosystems Engineering, 45, 6-37.

[68] Qu, Y.Y., Zhou, J.T., Wang, J., Xing, L.L., Jiang, N., Gou, M. and Uddin, M.S. (2009) Population Dynamics in Bioaugmented Membrane Bioreactor for Treatment of Bromoamine Acid Wastewater. Bioresource Technology, 100, 244-248. http://dx.doi.org/10.1016/j.biortech.2008.06.023

[69] Wichitsathian, B., Sindhuja, S., Visvanathan, C. and Ahn, K.H. (2004) Landfill Leachate Treatment by Yeast and Bacteria Based Membrane Bioreactors. Journal of Environmental Science and Health, Part A: Toxic/Hazardous Substances and Environmental Engineering, 39, 2391-2404. http://dx.doi.org/10.1081/ESE-200026295

[70] Hai, F.I., Yamamoto, K. and Fukushi, K. (2006) Development of a Submerged Membrane Fungi Reactor for Textile Wastewater Treatment. Desalination, 192, 315-322. http://dx.doi.org/10.1016/j.desal.2005.06.050

[71] Orshansky, F. and Narkis, N. (1997) Characteristics of Organics Removal by PACT Simultaneous Adsorption and Biodegradation. Water Research, 31, 391-398. http://dx.doi.org/10.1016/S0043-1354(96)00227-8

[72] Lesage, N., Sperandio, M. and Cabassud, C. (2008) Study of a Hybrid Process: Adsorption on Activated Carbon/ Membrane Bioreactor for the Treatment of an Industrial Wastewater. Chemical Engineering and Processing: Process Intensification, 47, 303-307. http://dx.doi.org/10.1016/j.cep.2007.01.021

[73] Hai, F.I., Yamamoto, K., Nakajima, F. and Fukushi, K. (2008) Removal of Structurally Different Dyes in Submerged Membrane Fungi Reactor-Biosorption/PAC-Adsorption, Membrane Retention and Biodegradation. Journal of Membrane Science, 325, 395-403. http://dx.doi.org/10.1016/j.memsci.2008.08.006

[74] Munz, G., Gori, R., Mori, G. and Lubello, C. (2007) Powdered Activated Carbon and Membrane Bioreactors (MBRPAC) for Tannery Wastewater Treatment: Long Term Effect on Biological and Filtration Process Performances. Desalination, 207, 349-360. http://dx.doi.org/10.1016/j.desal.2006.08.010

[75] Thuy, Q.T.T. and Visvanathan, C. (2006) Removal of Inhibitory Phenolic Compounds by Biological Activated Carbon Coupled Membrane Bioreactor. Water and Wastewater Management for Sustainable Development of Chemical Industries, 53, 89-97. http://dx.doi.org/10.2166/wst.2006.341

[76] Zou, H. and Xi, D. (2007). Performance of Bioferric-Submerged Membrane Bioreactor for Dyeing Wastewater Treatment. Frontiers of Environmental Science \& Engineering in China, 1, 374-380. http://dx.doi.org/10.1007/s11783-007-0064-7 


\section{List of Abbreviations}

\begin{tabular}{|c|c|c|}
\hline S. No & Abbreviations & Names \\
\hline 1 & $\mathbf{O}_{3}$ & ozone \\
\hline 2 & COD & Chemical Oxygen Demand \\
\hline 3 & LC-MS-MS & Chromatography-mass-spectrum-mass spectrum \\
\hline 4 & YES & Yeast estrogen screen \\
\hline 5 & WWTPs & waste water treatment plants \\
\hline 6 & TPAD & two-phase anaerobic digestion \\
\hline 7 & SBR & Sequencing Batch Reactor \\
\hline 8 & MBR & Membrane Bioreactor \\
\hline 9 & YMBR & yeast based membrane bioreactor \\
\hline 10 & EPS & extracellular polymeric substances \\
\hline 11 & CASS & Cyclic Activated Sludge System \\
\hline 12 & ICEAS & Intermittent Cycle Extended Aeration \\
\hline 13 & PAC & powdered activated carbon \\
\hline 14 & HMBR & hybrid membrane bioreactor \\
\hline 15 & AS-MBR & activated sludge coupled with MBR \\
\hline 16 & BAC-MBR & biological granular activated carbon coupled with MBR \\
\hline 17 & SMBR & submerged membrane bioreactor \\
\hline 18 & EDCs & Endocrine disrupting compounds \\
\hline 19 & BPA & Bisphenol A \\
\hline 20 & CAS & conventional activated sludge \\
\hline 21 & 5-TTri & 5-tolyltriazole \\
\hline 22 & AST & activated sludge treatment \\
\hline 23 & PhACs & pharmaceutically active compounds \\
\hline 24 & PCPs & personal care products \\
\hline 25 & FBBR & fixed-bed bioreactor \\
\hline 26 & ABS & acrylonitrile-butadiene-styrene \\
\hline 27 & ASMBR & aerated submerged membrane bioreactor \\
\hline 28 & GEM & genetically engineered microorganism \\
\hline 29 & SBR & sequencing batch reactor \\
\hline 30 & OMW & olive mill wastewater \\
\hline 31 & CF-MBR & crossflow membrane bioreactor \\
\hline 32 & RO & reverse osmosis \\
\hline 33 & HRT & hydraulic retention time \\
\hline 34 & DAF & dissolved air flotation \\
\hline 35 & VFA & volatile fatty acid \\
\hline 36 & VSS & Volatile suspended solids \\
\hline 37 & CASR & Conventional activated sludge reactor \\
\hline 38 & HRT & Hydraulic retention time \\
\hline 39 & EDCs & Endocrine disrupting chemicals \\
\hline
\end{tabular}

